\title{
MODEL PENGENDALIAN KEMISKINAN DENGAN PENDEKATAN DIVERSIFIKASI USAHA, SUSTAINABLE DEVELOPMENT GOALDS (SDGS) DAN ECONOMIC VALUE (STUDI PADA DAERAH PEMEKARAN DI SUMATERA UTARA)
}

\author{
Muhamad Toyib Daulay \\ Fakultas Ekonomi Universitas Pembangunan Panca Budi \\ Email: boboy daulay@yahoo.com
}

\begin{abstract}
This research has the goal of providing input to economic divesifikasi models which are the most consistent in increasing economic value and decrease poverty in the district town expansion North Sumatra Province. Provide input model Sustaianble Development Goals (SDGs) are the most supportive in the increase in economic value and alleviating poverty in the county town expansion North Sumatra Province. Prove empirically the performance of the economy which interact strongly supported the decline in poverty in the county town of the expansion in North Sumatra Province. This research uses 16 sample extraction area in North Sumatra. The first model of poverty alleviation through diversified value-added business community in meeting the needs of the community's life while the second model to determine what variables as policy recommendations for alleviating poverty in the County the expansion North Sumatra Province. The first model requires primary data while the second model requires data skunder time series starting in 2000 up to 2013. data analysis using two models, namely Structural Equation Models (SEM) and Vector Autoregression (VAR). Results of the study and this analysis gives an overview and prove the real poverty mapping in areas of expansion, poverty reduction actions based on the poverty mapping, control variables are very urgent in affects poverty, and controlling poverty continuously.
\end{abstract}

Key words: Poverty, SEM, VAR, SDGS

\section{PENDAHULUAN}

P

embangunan ekonomi memiliki ukuran pertumbuhan ekonomi yang tinggi. Pertumbuhan ekonomi salah satunya memiliki ukurang keberhasilan peningkatan kesejahteraan masyarakat. Kesejahteraan masyarakat yang rendah salah satunya memunculkan kemiskinan. Bukan hanya terjadi di Indonesia kemiskinan juga terjadi hampir di seluruh negara di dunia bahkan dalam negara yang maju sekalipun. Permasalahannya tidak berhenti sampai 
disitu saja, penduduk yang tergolong tidak miskin di suatu negara dapat menjadi relatif miskin dibandingkan dengan penduduk negara seperti Amerika Serikat (Kuncoro, 2004: 141). Oleh karena itu kemiskinan disebutsebut sebagai permasalahan global. Globalitas masalah kemiskinan yang begitu menyita perhatian dunia internasional tercermin sebagai salah satu target indikator perbaikan dunia yang tercantum dalam Millenium Development Goals (MDG's); yaitu menekan kemiskinan hingga 50 persen pada 2015.

Masalah-masalah yang dihadapi pada aspek ekonomi cukup beragam dan belum kondusif dalam menggerakkan investasi, pola belanja aparatur, dan pembangunan yang belum sepenuhnya mendukung perekonomian lokal karena masalah tempat tinggal aparatur, pemilihan ibukota kabupaten yang belum dapat menciptakan pusat perekonomian di pemekaran, keterbatasan berbagai infrastruktur penunjang ekonomi maupun penunjang pusat fasilitas pemerintahan. Keputusan untuk memekarkan suatu daerah harus dilakukan dengan sangat hati-hati. Sangat penting untuk mempersiapkan suatu daerah yang menginginkan pemekaran. Periode persiapan ini perlu disesuaikan dengan kondisi di lapangan. Dalam periode masa persiapan yang bisa jadi mencapai 10 tahun, maka pemerintah pusat dan daerah induk dapat melakukan fasilitasi dan persiapan hal-hal berikut: pengangkatan dan pengalihan aparatur pemerintahan sesuai fungsi dan kapasitasnya, penyiapan infrastruktur perekonomian dan fasilitas pemerintahan, serta infrastruktur penunjang bagi aparatur pemerintah beserta keluarganya. Setelah seluruh persiapan dan fasilitasi tersebut diberikan dalam waktu yang memadai, maka evaluasi selanjutnya akan menentukan apakah daerah tersebut memang akhirnya layak untuk dimekarkan atau tidak.

Selain persiapan dan pemberian fasilitasi, sumber daya yang adapun perlu diatur pembagiannya dengan seksama. Sumber daya tersebut meliputi: sumber daya alam, sumber daya manusia dan infrastruktur penunjang lainnya. Pembagian yang tidak merata atau memiliki kesenjangan yang terlalu besar akan berimplikasi pada tidak adanya perubahan yang signifikan, khususnya di daerah pemekaran. Oleh karena itu, peran pemerintah pusat dalam pembagian daerah pemekaran perlu dipertegas dalam perundangan yang berlaku. Pada aspek perekonomian daerah pemekaran, program-program pemerintah sebaiknya diarahkan pada 
upaya mendukung sektor utama yakni pertanian dalam arti luas, baik ketersediaan infrastuktur penunjang maupun tenaga-tenaga penyuluh di lapangan, dan lain sebagainya. Pengembangan sektor-sektor lainnya diarahkan pada upaya mendukung sektor utama sehingga percepatan di daerah pemekaran dapat terwujud. Di sektor pendidikan, studi yang lebih mendalam diperlukan untuk melihat penurunan angka partisipasi sekolah di daerah baru.

Pentingnya penelitian ini adalah berkaitan dengan fenomena pemekaran yang terjadi di Kabupaten Propinsi Sumatera Utara semakin menyebabkan kemiskinan terpinggirkan, khususnya terhadap kemiskinan wilayah pesisir dan pegunungan seperti Serdang Bedagai, Batubara, Labuhan Batu Utara, Labuhan Batu Selatan, Padang Lawas Utara, Padang Lawas Selatan, Humbang Hasundutan, Nias Barat, Nias Utara, Nias Selatan, Samosir dan Pakpak Bharat, sehingga diperlukan suatu landasan kuat yang menjadi formula dalam pengentasan kemiskinan daerah secara berkelanjutan (sustainable). Adapun arahan yang merupakan landasan dasar atau landasan hukum strategi pengentasan kemiskinan daerah ini adalah : Peraturan Presiden Republik Indonesia Nomnor 15 Tahun 2010 Tentang Percepatan Penanggulangan Kemiskinan, Peraturan Presiden Republik Indonesia Nomor 13 Tahun 2009 Tentang Koordinasi Penanggulangan Kemiskinan. Undang-Undang Nomor 17 Tahun 2007 tentang Rencana Pembangunan Jangka Panjang Nasional 2005-2025. Undang-Undang Nomor 11 Tahun 2009 tentang Kesejahteraan Sosial Undang-Undang Nomor 25 Tahun 2009 tentang Pelayanan Publik. Pembentukan Intitutional framework for sustainable development (IFSD) oleh United Nations, 2011. KTT Bumi (Rio+20) tahun 2012 dengan tema-Ekonomi Hijau dalam konteks pembangunan lestari dan penurunan angka kemiskinan. (green economy in the contex of sustainable development and poverty eradication).

Landasan tersebut sebagai dasar alasan kuat perlu adanya suatu model pengentasan kemiskinan secara sustainable. Model pengentasan kemiskinan tersebut harus didukung oleh adanya pembangunan berkelanjutan atau Sustainable development. Setelah sekian lama upayaupaya pembangunan perkotaan dan pedesaan di Indonesia, Sumatera Utara dan daerah pemekaran dilakukan, ternyata hasilnya belum seperti yang diharapkan. Kemudian untuk mendukung kesuksesan MDGS dan jalannya SDGS, Tahun 2010 United Nations Development Programme 
(UNDP) memperkenalkan Indeks Kemiskinan Multidimensional (MPI). Indeks MPI sebagai ukuran internasional baru dari kemiskinan melengkapi ukuran kemiskinan berbasis pendapatan dengan mencerminkan beberapa kekurangan yang dihadapi orang-orang pada saat yang sama di 104 negara berkembang.

MPI mengidentifikasi perampasan di kesehatan, pendidikan dan standar hidup, dan menunjukkan jumlah orang yang multidimensional miskin dan kekurangan yang mereka hadapi di tingkat rumah tangga.

MPI tersebut diyakini mampu mengurangi permasalahan pembangunan. Permasalahan pembangunan yang belum terpecahkan dan masih menuntut perhatian antara lain adalah masih belum adanya identifikasi penduduk miskin menyebabkan strategi pengentasan kemiskinan daerah kurang maksimal. Belum adanya formula khusus yang digunakan oleh pemerintah daerah dalam pengentasan kemiskinan. Adanya kesenjangan pembangunan antar daerah (disparitas), urban primacy yang cukup tinggi, relasi atau keterkaitan antara perkotaan dan perdesaan yang kurang sinergis, wilayah-wilayah yang tertinggal dan persoalan kemiskinan. Belum ada model koordinasi yang jelas dalam mengimplementasikan MDGS dan SDGs sebagai salah satu model kemiskinan daerah. Diversifikasi usaha tani dan nelayan yang masih belum menemukan value added yang tinggi. Masyarakat masih menganggap usaha mencari pendapatan hanya diperoleh dari satu sumber saja dan tidak ada keinginan untuk meningkatkan economic value added dengan menambah atau merubah cara meningkatkan kesejahteraan. Hal tersebut yang membuat kemiskinan sulit teratasi. Bahkan tingkat persoalan kemiskinan semakin besar setelah krisis ekonomi terjadi tahun 1998 dan tahun 2008. Disparitas (kesenjangan) pembangunan antar daerah dapat dilihat darikesenjangan dalam:

1. Pendapatan perkapita,

2. Kualitas sumber daya manusia,

3. Ketersediaan sarana dan prasarana seperti transportasi, energi dan telekomunikasi,

4. Pelayanan sosial seperti kesehatan, pendidikan, dan lain sebagainya, dan 


\section{Akses ke perbankan.}

Pengurangan angka kemiskinan menjadi tujuan utama dari MDGs ini. Hal initerlihat dari poin pertama komponen besar MDGs yang semuanya ditargetkan padatahun 2015. Namun, yang perlu diperhatikan saat ini ialah mengenai bagaimanaefektivitas MDGs ini dalam menanggulangi permasalahan kemiskinan sebagai permasalahan sosial, serta bagaimana komitmen dan kerjasama yang dilakukan olehnegara berkembang dan negara maju dalam mewujudkan tujuan MDGs dengan sisawaktu lima tahun dari yang ditargetkan ini.Paper ini merupakan sumbangan pemikiran yang dapat digunakan sebagaiacuan berpikir dalam melihat perkembangan MDGs hingga saat ini.

Berdasarkan beberapa kajian kuantitatif baik sosial, ekonomi, kependudukan dan ketenagakerjaan. Propinsi Sumatera Utara tidak memiliki data tentang penduduk miskin secara riil dan pemetaan penduduk miskin. Pemetaan penduduk miskin memungkinkan pengambilan kebijakan dalam pengentasan kemiskinan. Pemetaan penduduk miskin didasarkan atas pertimbangan : wilayah (kota, desa, pesisir), pekerjaan (petani, nelayan, lainnya), tingkat pendidikan (SD, SMP, SMA), jumlah keluarga, akses ekonomi (jarak dengan pusat kota, jarang dengan jalan kabupaten/kecamatan), akses pendanaan/kredit/pinjaman (jarak dari bank/non bank, jumlah kredit yang diperoleh, kemudahan mendapatkan pendanaan).

Akses penyaluran hasil nelayan, petani (pasar, koperasi). Akses jaminan stabilitas harga (agen, distributor, koperasi). Kajian dan analisis ini akan memberikan gambaran dan membuktikan secara riil pemetaan kemiskinan daerah pemekaran, tindakan pengentasan kemiskinan berdasarkan pemetaan kemiskinan, pengendalian variabel yang sangat urgen dalam mempengaruhi kemiskinan, dan pengendalian kemiskinan secara terus menerus.

\section{METODE PENELITIAN}

Ruang lingkup penelitian ini difokuskan pada model pengentasan kemiskinan yang terbagi ke dalam dua model yaitu model diversivikasi ekonomi masyarakat dan model interaksi kinerja ekonomi terhadap kemiskinan. Kemiskinan diukur dengan indeks multidimensional kemiskinan atau MPI (Multidimentional Poverty Index). Model pertama QE J ournal | Vol.06 - N o. 03 December 2017 - 207 
pengentasan kemiskinan melalui diversifikasi nilai tambah usaha masyarakat dalam memenuhi kebutuhan hidup masyarakat sedangkan model kedua menentukan variabel apa saja sebagai rekomendasi kebijakan untuk pengentasan kemiskinan di kabupaten pemekaran Propinsi Sumatera Utara. Model pertama membutuhkan data primer sedangkan model kedua membutuhkan data skunder time series mulai tahun 2000 sampai dengan 2015.

Menurut Sims (Manurung,2005) jika simultanitas antara beberapa variabel benar maka dapat dikatakan bahwa variabel tidak dapat dibedakan mana variabel endogen dan mana variabel eksogen. Pengujian hubungan simultan dan derajat integrasi antar variabel dalam jangka panjang variabel yang mempengaruhi kemiskinan menggunakan metode VAR. Pengujian ini dilakukan untuk mengetahui ada tidaknya hubungan simultan (Saling terkait) antara variabel inflasi, pengangguran dan PDRB sebagai variabel eksogen terhadap kemiskinan sebagai variabel endogen dengan memasukkan unsur waktu (lag). Pengujian VAR dengan rumus :

$$
\begin{aligned}
& \log P D R B t=\alpha 1 \log I N F t-p+\alpha 2 \log P N G G t-p+\alpha 3 \log K M S K t-p+e t \\
& .1 \\
& \log I N F t=\alpha 1 \log P G N G G t-p+\alpha 32 \log K M S K t-p+\alpha 3 \log P D R B t-p+ \\
& \text { et................2 } \\
& \log P N G G t=\alpha 1 \log K M S K t-p+\alpha 2 \log P D R B t-p+\alpha 3 \log I N F t-p+e t \\
& \text {................ } 3 \\
& \log K M S K t=\alpha 1 \log P D R B t-p+\alpha 2 \operatorname{LogINFt}-p+\alpha 3 \log P N G G t-p+e t \\
& \text {................ } 4
\end{aligned}
$$

\section{Dengan :}

KMSK = Tingkat kemiskinan (orang)

INF = Inflasi (\%)

PGG $\mathrm{t}=$ Pengangguran (orang)

PDRB = PDRB Medan harga konstan (Rp)

$$
\begin{array}{ll}
\mathrm{a}, \mathrm{b} & =\text { koefisien } \\
\mathrm{C} & =\text { konstanta } \\
\mathrm{e} & =\text { kesalahan penganggu/residual (error terms) } \\
\mathrm{p} & =\text { panjang lag }
\end{array}
$$




\section{HASIL DAN PEMBAHASAN}

\section{Confirmatory Factor Analysis (CFA)}

CFA adalah bentuk khusus dari analisis faktor. CFA digunakan untuk menilai hubungan sejumlah variabel yang bersifat independent dengan yang lain. Analisis faktor merupakan teknik untuk mengkombinasikan pertanyaan atau variabel yang dapat menciptakan faktor baru serta mengkombinasikan sasaran untuk menciptakan kelompok baru seraca berturut-turut.

Ada dua jenis pengujian dalam tahap ini yaitu: Confirmatory Factor Analysis (CFA) yaitu measurement model dan structual equation model (SEM). CFA measurement model diarahkan untuk menyelidiki unidimensionalitas dari indikator-indikator yang menjelaskan sebuah faktor atau sebuah variabel laten. Seperti halnya dalam CFA, pengujian SEM juga dilakukan dengan dua macam pengujian yaitu uji kesesuaian model dan uji signifikansi kausalitas melalui uji koefisien regresi. Langkah analisis untuk menguji model penelitian dilakukan melalui tiga tahap yaitu pertama: menguji model konseptual. Jika hasil pengujian terhadap model konseptuap ini kurang memuaskan maka dilanjutkan dengan tahap kedua yaitu dengan memberikan perlakukan modifikasi terhadap model yang dikembangkan setelah meperhatikan indeks modifikasi dan dukungan (justifikasi) dari teori yang ada.

Selanjutnya, jika pada tahap kedua masih diperoleh hasil yang kurang memuaskan, maka ditempuh tahap ketiga dengan cara menghilangkan atau menghapus (drop) variabel yang memiliki nilai C.R (Critical Rasio) yang lebih kecil dari 1.96, karena variabel ini dipandang tidak berdimensi sama dengan variabel lainnya untuk menjelaskan sebuah variabel laten (Ferdinand, 2002:132). Loading factor atau lamda value $(\lambda)$ ini digunakan untuk menilai kecocokan, kesesuaian atau unidimensionalitas dari indikator-indikator yang membentuk dimensi atau variabel. Untuk menguji CFA dari setiap variabel terhadap model keseluruhan memuaskan atau tidak adalah berpedoman dengan kepada kriteria goodness of fit.

\section{CFA Variabel Usaha Penangkapan Ikan}

Variabel usaha penangkapan ikan memiliki 4 (empat) indikator yang akan diuji, yaitu : UPI1 = kapal tergolong sedang/bermesin UPI2 = kapal kecil atau sampan dayung UPI3 = pancing, kail, jala, jaring manual UPI4 = tidak QE Journal | Vol.06 - No. 03 December 2017 - 209 
memiliki alat penangkapan Berikut hasil gambar uji AMOS 20 dengan analisis CFA.

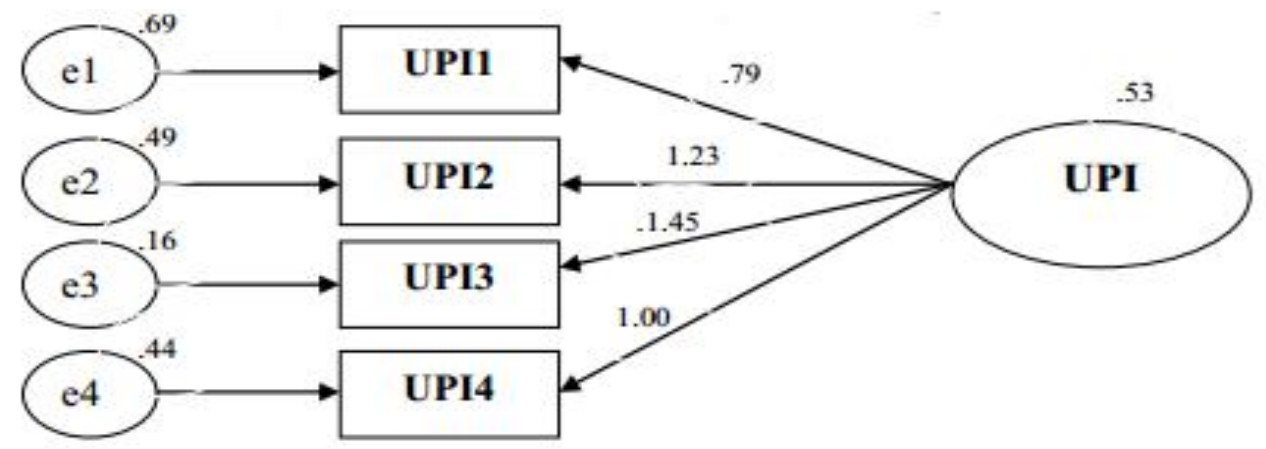

Gambar 1.1 CFA Usaha Penangkapan Ikan

Berdasarkan output AMOS diketahui bahwa seluruh indikator pembentuk konstruk firs order usaha penangkapan ikan memiliki nilai loading factor signifikan, dimana seluruh nilai loading factor melebihi angka 0,5. Jika seluruh indikator pembentuk konstruk sudah signifikan maka dapat digunakan dalam mewakili analisis data.

CFA Variabel Usaha Peternakan Dan Tambak

Variabel usaha peternakan dan tambak memiliki 3 (tiga) indikator yang akan diuji, yaitu : USPET1 = direct money cost USPET2 = time cost USPET3 = psycological Berikut hasil gambar uji AMOS 20 dengan analisis CFA.

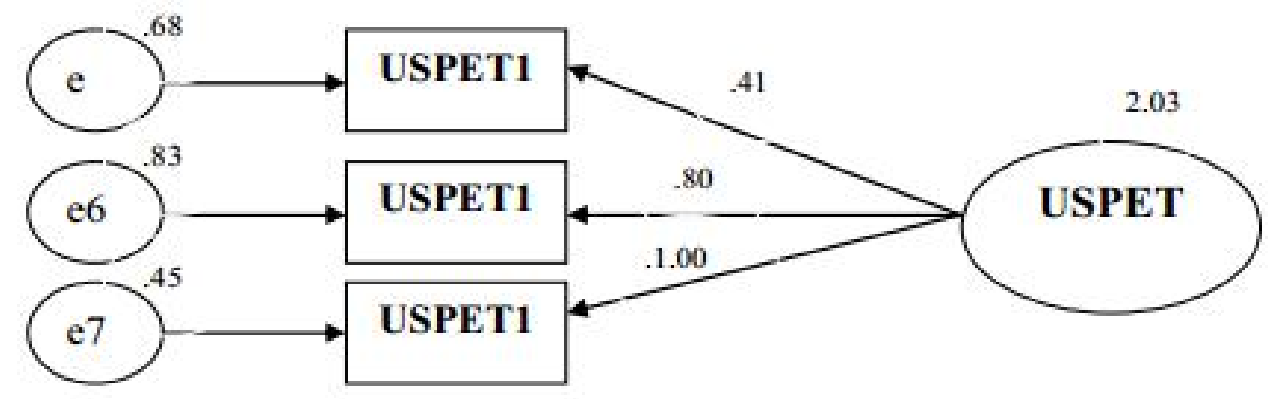

Gambar 1.2 CFA Usaha Peternakan dan Tambak

Berdasarkan output AMOS diketahui bahwa seluruh indikator pembentuk konstruk firs order usaha peternakan dan tambak memiliki nilai loading factor signifikan, dimana seluruh nilai loading factor melebihi angka 0,5. Jika seluruh indikator pembentuk konstruk sudah signifikan maka dapat digunakan dalam mewakili analisis data. 
CFA Variabel Pendidikan

Variabel pendidikan memiliki 5 (lima) indikator yang akan diuji, yaitu : PDDK1 = Akses sekolah dekat PDDK2 = Pendidikan gratis PDDK3 = Pendidikan berkualitas Berikut hasil gambar uji AMOS 20 dengan analisis CFA

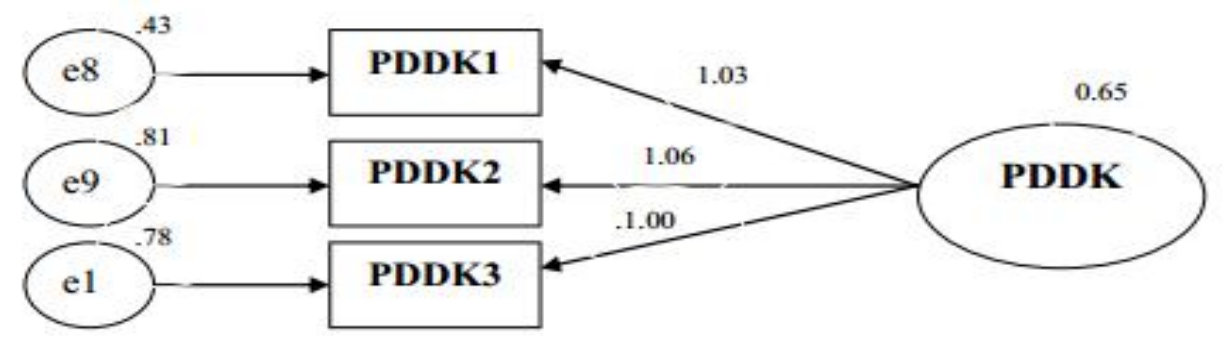

Gambar 1.3 CFA Pendidikan

Berdasarkan output AMOS diketahui bahwa seluruh indikator pembentuk konstruk firs order pendidikan memiliki nilai loading factor signifikan, dimana seluruh nilai loading factor melebihi angka 0,5. Jika seluruh indikator pembentuk konstruk sudah signifikan maka dapat digunakan dalam mewakili analisis data.

CFA Variabel Akses terhadap air bersih

Variabel pendidikan memiliki 5 (lima) indikator yang akan diuji, yaitu : $\mathrm{AAB1}=$ kemudahan mendapatkan air bersih $\mathrm{AAB1}$ = kemudahan dalam mendapatkan dengan harga murah dan terjangkau $\mathrm{AAB} 1=$ keberlanjutan untuk mendapatkan air bersih dalam waktu yang akan datang Berikut hasil gambar uji AMOS 20 dengan analisis CFA

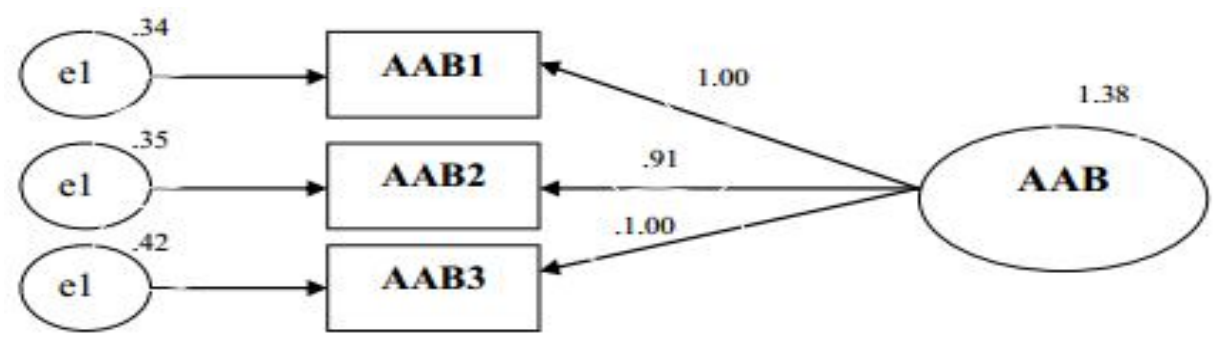

Gambar 1.4 CFA Akses terhadap air bersih

Berdasarkan output AMOS diketahui bahwa seluruh indikator pembentuk konstruk firs order akses air bersih memiliki nilai loading factor signifikan, dimana seluruh nilai loading factor melebihi angka 0,5. Jika seluruh 
indikator pembentuk konstruk sudah signifikan maka dapat digunakan dalam mewakili analisis data.

CFA Variabel Economic value

Variabel economic value memiliki 4 (empat) indikator yang akan diuji, yaitu : ECVAL1 = peningkatan atas aktivitas ECVAL2 = peningkatan pendapatan ECVAL3 = peningkatan kesejahteraan masyarakat Berikut hasil gambar uji AMOS 20 dengan analisis CFA

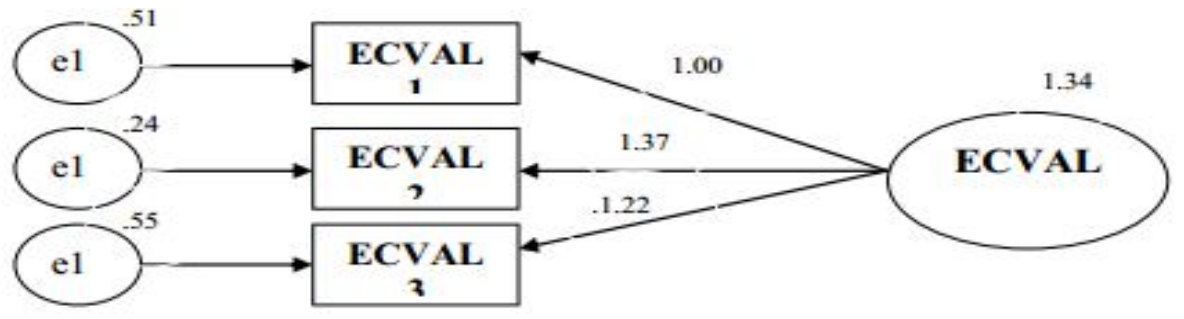

Gambar 1.5 CFA Economic value

Berdasarkan output AMOS diketahui bahwa seluruh indikator pembentuk konstruk firs order economic value memiliki nilai loading factor signifikan, dimana seluruh nilai loading factor melebihi angka 0,5. Jika seluruh indikator pembentuk konstruk sudah signifikan maka dapat digunakan dalam mewakili analisis data.

CFA Variabel Kemiskinan

Variabel kemiskinan memiliki e (empat) indikator yang akan diuji, yaitu: KMSK1 = kemudahan untuk mendapatkan uang KMSK2 $==$ kemudahan kepemilikan lahan KMSK3 = kondisi rumah KMSK4 = akses terhadap transportasi dan kondisi infrastruktur Berikut hasil gambar uji AMOS 20 dengan analisis CFA

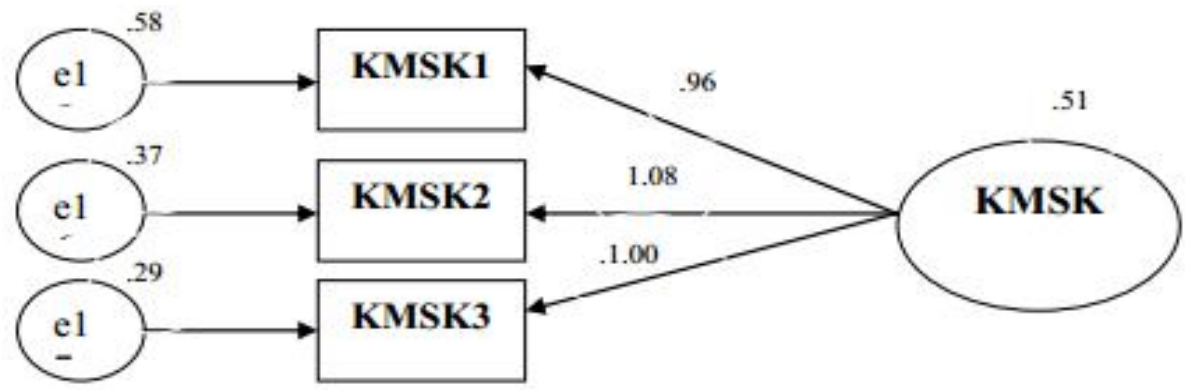

Gambar 1.6 CFA Kemiskinan

QE J ournal | Vol.06 - N 0.03 December 2017 - 212 
Berdasarkan output AMOS diketahui bahwa seluruh indikator pembentuk konstruk firs order kemiskinan memiliki nilai loading factor signifikan, dimana seluruh nilai loading factor melebihi angka 0,5. Jika seluruh indikator pembentuk konstruk sudah signifikan maka dapat digunakan dalam mewakili analisis data.

\section{Pengujian Hipotesis}

Untuk mengetahui hasil pengujian hipotesis dilakukan dengan melihat nilai probabilitas (probability) atau dengan melihat signifikansi dari keterkaitan masing-masing variabel penelitian. Adapun kiriterianya adalah jika $\mathrm{P} \varangle 0.05$ maka hubungan antar variabel adalah signifikan dan dapat dianalisis lebih lanjut, dan sebaliknya. Oleh karenanya, dengan melihat angka probabilitas (p) pada output Dari keseluruhan jalur menunjukkan nilai yang signifikan pada level $5 \%$ atau nilai standardize harus lebih besar dari 1.96 (>1.96). (Jika menggunakan nilai perbandingan nilai $t$ hitung dengan $\mathrm{t}$ tabel, berarti nilai $\mathrm{t}$ hitung di atas 1.96 atau $>1.96$ atau $t$ hitung lebih besar dari $t$ tabel). AMOS 20 dapat ditetapkan kriteria penerimaan dan penolakan hipotesis sebagai berikut:

Jika P >0.05 maka H0 diterima (tidak signifikan)

Jika P <0.05 maka H0 ditolak (siginifikan) (Santoso, 2007)

Hipotesis dalam penelitian ini terbagi ke dalam 3 (tiga) pengujian, yaitu:

1. Usaha penangkapan ikan, usaha peternakan dan tambak, pendidikan dan akses terhadap air bersih berpengaruh positif terhadap economic value di Batu Bara.

2. Usaha penangkapan ikan, usaha peternakan dan tambak, pendidikan dan akses terhadap air bersih berpengaruh positif terhadap kemiskinan di Batu Bara.

3. Usaha penangkapan ikan, usaha peternakan dan tambak, pendidikan dan akses terhadap air bersih berpengaruh positif terhadap economic value dan kemiskinan di Batu Bara.

Berdasarkan tabel di atas diketahui :

1. Terdapat pengaruh signifikan usaha peternakan dan tambak, pendidikan dan akses terhadap air bersih berpengaruh positif terhadap economic value di Batu Bara, dimana nilai probabilitas memiliki bintang tiga. Terdapat pengaruh tidak signifikan usaha penangkapan ikan terhadap economic value masyarakat miskin di Batu Bara. 
2. Terdapat pengaruh signifikan usaha penangkapan ikan, usaha peternakan dan tambak dan akses terhadap air bersih terhadap kemiskinan masyarakat miskin di Batu Bara, dimana nilai probabilitas memiliki bintang tiga. Terdapat pengaruh tidak signifikan pendidikan terhadap kemiskinan masyarakat miskin di Batu Bara, dimana nilai probabilitas sebesar 0,969>0,05 sehingga diketahui pendidikan tidak signifikan mempengaruhi kepatuhan.

3. Usaha penangkapan ikan, pendidikan, akses terhadap air bersih economic value berpengaruh positif terhadap economic value dan kemiskinan masyarakat miskin di Batu Bara. Namun usaha peternakan dan tambak berpengaruh negatif terhadap economic value dan pendidikan berpengaruh negatif terhadap kemiskinan masyarakat miskin di Batu Bara.

Pembahasan Model Kedua Vector Autoregression Kemiskinan

Variabel Produk Domestik Regional Bruto, kontribusi yang paling besar terhadap Produk Domestik Regional Bruto (PDRB) adalah PDRB satu semester sebelumnya kemudian disusul oleh kemiskinan satu semester sebelumnya. Selain PDRB itu sendiri yang mendorong naiknya PDRB tahun sekarang tapi juga didukung dengan naiknya kemiskinan. Naiknya kemiskinan akan meningkatkan peengeluaran, naiknya pengeluaran akan mendorong naiknya kapasitas produksi sehingga PDRB juga akan meningkat.

Variabel Pendapatan asli daerah, kontribusi yang paling besar terhadap pendapatan asli daerah adalah PDRB satu semester sebelumnya dan pengangguran satu semester sebelumnya. Naiknya PDRB akan meningkatkan pendapatan perkapita penduduk sehingga banyak penduduk yang masuk dalam pendapatan asli daerah baru. Variabel Inflasi, kontribusi yang paling besar terhadap inflasi adalah inflasi satu semester sebelumnya dan pendapatan asli daerah satu semester sebelumnya. Naiknya inflasi akan meningkatkan inflasi tahun yang akan datang.

Variabel Pengangguran Kontribusi yang paling besar terhadap Pengangguran selain Pengangguran itu sendiri adalah PDRB satu semester sebelumnya. Naiknya PDRB akan meningkatkan pendapatan perkapita penduduk, naiknya pendapatan perkapita akan meningkatkan permintaan 
masyarakat terhadap suatu barang, naiknya permintaan akan menurunkan pengangguran meningkat.

Variabel kemiskinan kontribusi yang paling besar terhadap kemiskinan adalah PDRB satu semester sebelumnya dan Pengangguran satu semester sebelumnya. Naiknya PDRB akan meningkatkan pendapatan perkapita penduduk sehingga banyak penduduk yang menyumbang dalam pendapatan asli daerah baru dan membayar sejumlah pajak daerah.

Berdasarkan hasil Vector Autoregression diketahui bahwa variabel sebelumnya juga mempengaruhi. Dimana dapat ditunjukkan pada lampiran tabel hasil estimasi VAR bahwa variabel masa lalu (t-1) berpengaruh signifikan terhadap dirinya sendiri dan variabel lain. Dari hasil estimasi tersebut di atas beserta uraiannya ternyata hubungan timbal balik antara variabel Produk Domestik Regional Bruto (PDRB), Pendapatan Asli Daerah (PAD), inflasi (INF), Kemiskinan (KMSK), Pengangguran (PGGR) menjadi semakin jelas dan dengan demikian hipotesa adanya hubungan timbal balik antara Produk Domestik Regional Bruto (PDRB), Pendapatan Asli Daerah (PAD), inflasi (INF), Kemiskinan (KMSK), Pengangguran (PGGR) sebagai variabel yang diamati dalam penelitian ini terbukti. Model VAR sesuai dengan ekspektasi perekonomian daerah lain di masa mendatang, hal tersebut dapat ditunjukkan pada trend beberapa variabel yang berfluktuasi.

Tabel 1.3 Ringkasan Hasil Variance Decomposition

\begin{tabular}{|c|c|c|c|c|c|}
\hline $\begin{array}{l}\text { Periode } \\
\text { Jangka }\end{array}$ & PDRB & PAD & INF & PGGR & KMSK \\
\hline Pendek & $\begin{array}{l}\text { Terbesar } 1 \\
\text { PDRB } 100 \%\end{array}$ & $\begin{array}{l}\text { Terbesar } 1 \\
\text { PAD } 81,62 \% \\
\text { Terbesar } 2 \\
\text { PDRB } \\
18,38 \% \\
\end{array}$ & $\begin{array}{l}\text { Terbesar } 1 \\
\text { Inflasi } 86,88 \% \\
\text { Terbesar } 2 \\
\text { PDRB } 6,95 \%\end{array}$ & $\begin{array}{l}\text { Terbesar } 1 \\
\text { Pengangguran } \\
64,87 \% \\
\text { Terbesar } 2 \\
\text { PDRB } 10,17 \% \\
\end{array}$ & $\begin{array}{l}\text { Terbesar } 1 \\
\text { PAD 59,96\% } \\
\text { Terbesar } 2 \\
\text { KMSK } 31,07 \%\end{array}$ \\
\hline $\begin{array}{l}\text { Menen } \\
\text { gah }\end{array}$ & $\begin{array}{l}\text { Terbesar } 1 \\
\text { PDRB } 70,89 \% \\
\text { Terbesar } 2 \\
\text { Pengangguran } \\
12,32 \%\end{array}$ & $\begin{array}{l}\text { Terbesar } 1 \\
\text { PDRB } \\
48,41 \% \\
\text { Terbesar } 2 \\
\text { PAD } 27,19 \% \\
\end{array}$ & $\begin{array}{l}\text { Terbesar } 1 \\
\text { Inflasi } \\
477,25 \% \\
\text { Terbesar } 2 \\
\text { PDRB } 12,47 \% \\
\end{array}$ & $\begin{array}{l}\text { Terbesar } 1 \\
\text { Pengangguran } \\
41,95 \% \\
\text { Terbesar } 2 \\
\text { PDRB } 40,51 \% \\
\end{array}$ & $\begin{array}{l}\text { Terbesar } 1 \\
\text { PDRB } 52,94 \% \\
\text { Terbesar } 2 \\
\text { PAD } 18,23 \%\end{array}$ \\
\hline Panjang & $\begin{array}{l}\text { Terbesar } 1 \\
70,83 \% \\
\text { Terbesar } 2 \\
\text { Pengangguran } \\
12,41 \%\end{array}$ & $\begin{array}{l}\text { Terbesar } 1 \\
\text { PDRB } \\
48,41 \% \\
\text { Terbesar } 2 \\
\text { PAD } 27,19 \%\end{array}$ & $\begin{array}{l}\text { Terbesar } 1 \\
\text { Inflasi } 77,06 \% \\
\text { Terbesar } 2 \\
\text { PDRB } 12,59 \%\end{array}$ & $\begin{array}{l}\text { Terbesar } 1 \\
\text { Pengangguran } \\
41,62 \% \\
\text { Terbesar } 2 \\
\text { PDRB } 40,94 \%\end{array}$ & $\begin{array}{l}\text { Terbesar } 1 \\
\text { PDRB 53,05\% } \\
\text { Terbesar } 2 \\
\text { PAD } 18,05 \%\end{array}$ \\
\hline
\end{tabular}

Sumber : hasil uji VAR 
Berdasarkan hasil decomposition terhadap Kemiskinan (KMSK) diketahui bahwa rekomendasi dalam jangka pendek untuk mengendalikan kemiskinan adalah pendapatan asli daerah $(59,96 \%)$. Naiknya pendapatan asli daerah akan meningkatkan kemiskinan, jadi dalam jangka pendek pemerintah Kabupaten Batu Bara harus memperbanyak pendapatan asli daerah sehingga secara langsung mampu menurunkan angka kemiskinan.

Dalam jangka menengah rekomendasi untuk pengendalian kemiskinan adalah PDRB (52,94\%). Kemudian dalam jangka panjang rekomendasi untuk pengendalian kemiskinan adalah PDRB (53,05\%). PDRB yang meningkat akan mendorong naiknya masyarakat dalam beraktivitas dan naiknya pendapatan masyarakat.

Pembahasan Model Ketiga Pemetaan Kemiskinan Model pemetaan kemiskinan berdasarkan analisis AMOS dan VAK di atas menujukkan model yang memetakan kemiskinan berdasarkan beberapa pertimbangan berikut:

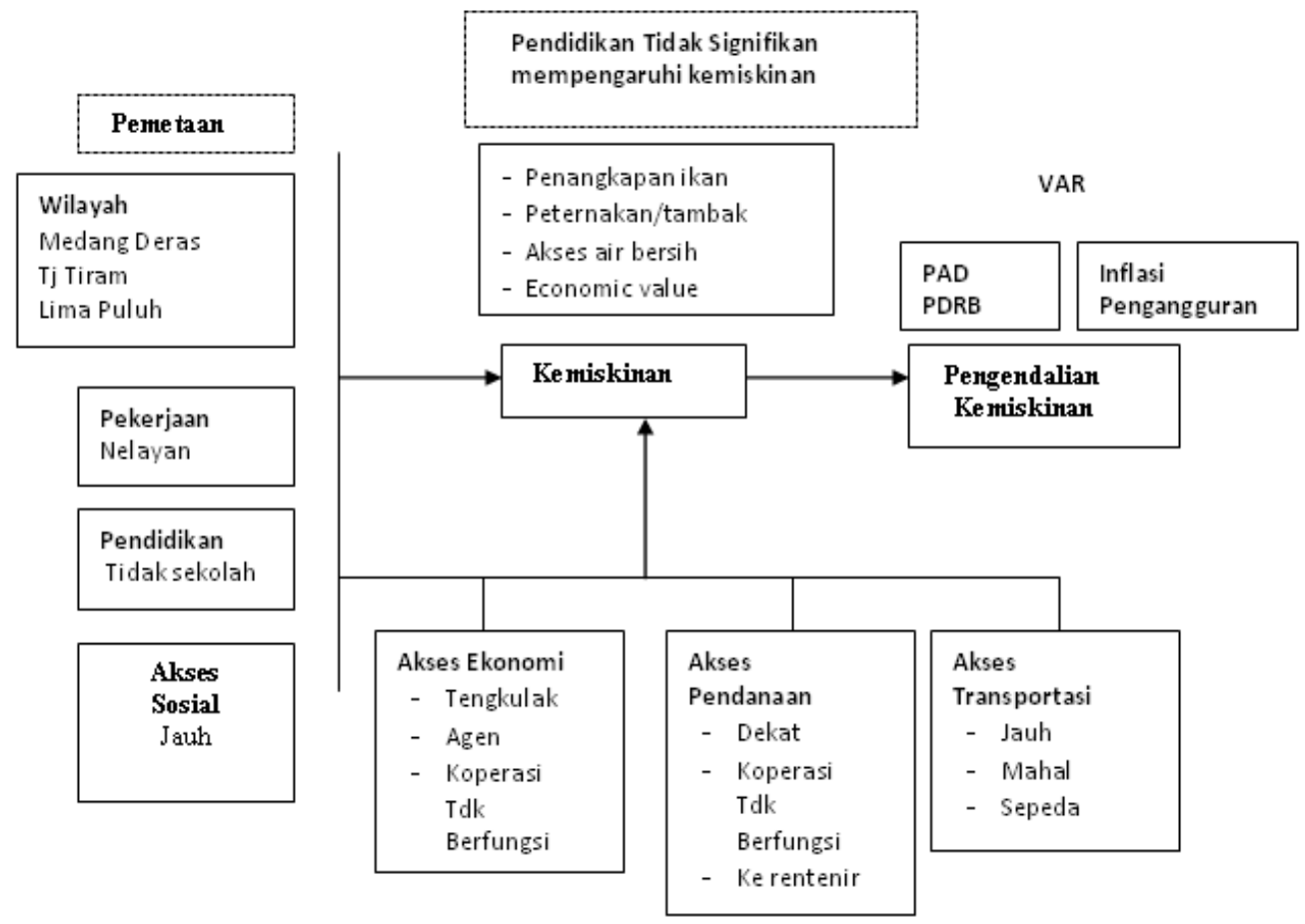

Gambar 1.7 Pemetaan Pengendalian Kemiskinan 
1. Hasil pemetaan terhadap analisis data pada gambar di atas menunjukkan bahwa ternyata pendidikan tidak cukup nyata dalam mempengaruhi kemiskinan di Batu Bara.

2. Pengendalian penduduk miskin dilakukan dengan strategi peningkatan PAD dan PDRB Batu Bara.

3. Penduduk miskin yang paling banyak dijumpai adalah di wilayah pesisir dengan mata pencarian sebagai nelayan.

4. Sebagian besar penduduk miskin tidak sekolah dan tidak tamat sekolah dasar.

5. Akses terhadap ekonomi tidak didukung oleh peran koperasi melainkan peran tengkulak/agen.

6. Akses terhadap pendanaan tidak didukung oleh peran koperasi dan lebih berperan ke rentenir

7. Akses transportasi masih jauh dan ongkos yang masih mahal dengan alat transportasi sebagian besar hanya sepeda.

8. Usaha penangkapan ikan tidak meningkatkan economic value sehingga kesejahteraan tidak meningkat.

9. Pendidikan tidak signifikan mempengaruhi kemiskinan sehingga masyarakat hanya membutuhkan tenaga fisik untuk memenuhi kebutuhan hidup.

Terdapat pengaruh signifikan usaha peternakan dan tambak, pendidikan dan akses terhadap air bersih terhadap economic value di Batu Bara, dimana nilai probabilitas memiliki bintang tiga. Terdapat pengaruh tidak signifikan usaha penangkapan ikan terhadap economic value masyarakat miskin di Batu Bara. Terdapat pengaruh signifikan usaha penangkapan ikan, usaha peternakan dan tambak dan akses terhadap air bersih terhadap kemiskinan masyarakat miskin di Batu Bara, dimana nilai probabilitas memiliki bintang tiga. Terdapat pengaruh tidak signifikan pendidikan terhadap kemiskinan masyarakat miskin di Batu Bara, dimana nilai probabilitas sebesar $0,969>0,05$ sehingga diketahui pendidikan tidak signifikan mempengaruhi kepatuhan.

Usaha penangkapan ikan, pendidikan, akses terhadap air bersih economic value berpengaruh positif terhadap economic value dan kemiskinan masyarakat miskin di Batu Bara. Namun usaha peternakan dan tambak berpengaruh negatif terhadap economic value dan pendidikan berpengaruh negatif terhadap kemiskinan masyarakat miskin di Batu Bara. 


\section{SIMPULAN DAN SARAN}

Berdasarkan hasil analisis dan pembahasan yang telah dilakukan, maka dapat diambil kesimpulan sebagai berikut :

1. Berdasarkan hasil analisa Vector Autoregression diketahui bahwa satu variabel pada semester lalu ( $\mathrm{t}-1)$ berpengaruh signifikan terhadap variabel itu sendiri dan variabel lain yang ditunjukan pada

a. Kemiskinan tahun sebelumnya, pertumbuhan ekonomi, pendapatan asli daerah, inflasi, dan Pengangguran berpengaruh terhadap kemiskinan.

b. Pertumbuhan ekonomi tahun sebelumnya, pendapatan asli daerah, inflasi, Pengangguran, kemiskinan berpengaruh terhadap pertumbuhan ekonomi.

c. Pendapatan asli daerah tahun sebelumnya, inflasi, Pengangguran, kemiskinan dan pertumbuhan ekonomi berpengaruh terhadap pendapatan asli daerah.

d. Inflasi tahun sebelumnya, Pengangguran, kemiskinan, pertumbuhan ekonomi dan pendapatan asli daerah berkontribusi terhadap inflasi

e. Pengangguran sebelumnya, kemiskinan, pertumbuhan ekonomi, pendapatan asli daerah dan inflasi berpengaruh terhadap pengangguran

2. Hasil analisis Impulse Response Function untuk kemiskinan menunjukan bahwa respon kenaikan satu standar deviasi kemiskinan pada semester 1 dan semester 2 akan cendrung membawa efek positif terhadap variabel seperti jumlah PDRB, pendapatan asli daerah, Pengangguran dan inflasi.

3. Berdasarkan hasil Analisis Varian Decomposition terhadap kemiskinan penduduk diketahui bahwa rekomendasi dalam jangka pendek untuk mengendalikan kemiskinan adalah pendapatan asli daerah di Kabupaten Batu Bara. 


\section{DAFTAR PUSTAKA}

Arana, Mario J. (2004). Macroeconomic Adjustment and Poverty: The Case of Nicaragua.

Aranibar, Jaime (2000). Bolivia, Economic Performance and Social Issues from the 80's up to date. La Paz, Bolivia. The Task Force on National Strategies for Sustainable Development. March.

Bardhan, Pranab and Samuel Bowles (1998). The Effects of Inequality on Economic Performance: A Progress Report and Proposal. October.

Barros, Ricardo Paes de, Carlos Corseuil, Rosane Mendonça and Maurício Cortez Reis (2000).

Bird, Kelly and Chris Manning (2008). Minimum Wages and Poverty in a Developing Country:

Blakely Fransisco L R dan Bradshaw A. Reivera Batiz, 2000, Iternational Finance and Open Economy Macroeconomic, Second Edition, New York, Macmillan Publishing Company.

Boediono. 2000, Ekonomi Moneter, Edisi 3, BPFE, Yogyakarta. Budiono (2002), Ekonomi Internasional, BPFE UGM, Yogyakarta.

Badan Pusat Statistik, Jakarta. Chambers. 1987. Pembangunan Desa Mulai dari Belakang. Jakarta: LP3ES

BPS, 2004. Monitoring dan Kajian terhadap Program Kemiskinan di Indonesia, Jakarta. Cameron, Lisa A. (2000). Poverty and Inequality in Java: Examining the Impact of the Daulay, Murni (2009). Kemiskinan Pedesaan. Edisi Pertama. Medan USU Press. Dissertation. University of Illinois, Urbana.

Djoko Sugeng Pudjianto, Kristiani 2006. Kemiskinan, Kondisi Geografis dan Fasilitas Pelayanan Kesehatan yang Berhubungan dengan Kejadian Kekurangan Energi Protein (KEP) pada Balita di Kabupaten Sragen.

Dornbusch, Rudriger and Fisher, Stanley.,2004. -Macroeconomics II, 6th, ed International Edition, McGraw-Hill. Inc.

Doktor. Sekolah Pascasarjana, Institut Pertanian Bogor, Bogor. 
Global Reporting Initiative (GRI). Indicator Protocols Set: EC 2000 - 2006 yang di- download dari www.google.com tanggal 15 Agustus 2008.

Greene, Pillanueva, 2001, Intermediate Microeconomic and Its Applications, 9th Edition, Thomson, Soutwestern.

Munandar, Kurniawan, Santoso (2007) Mencari Hubungan Antara Kebijakan Moneter Dengan Kemiskinan Dan Ketimpangan Pendapatan: Kajian Menggunakan Data Regional Indonesia. Jurnal. Direktorat Riset Ekonomi dan Kebijakan Moneter, Bank Indoneisa, Jl. M.H. Thamrin No. 2, Jakarta 10350, Indonesia; email: hmunandar@bi.go.id.

Muhammad Edi Kiurniawan (2008) Interaksi Antara Kinerja Ekonomi Dan Kemiskinan di Kabupaten Kutai Kartanegara. Penelitian ini merupakan hasil kerjasama antara PPIPD Magister Ekonomika Pembangunan, Universitas Gadjah Mada dengan Bappeda Kabupaten Kutai Kartanegara.

Ikhsan, M. 1999. The Disaggregation of Indonesian Poverty : Policy and Analysis. Ph.D. International Monetary Fund (2006). Cambodia: Poverty Reduction Strategy Paper.

Washington, D.C. IMF Country Report No. 06/266. July.

Kartasasmita, Ginanjar (1996), "Pemberdayaan Masyarakat: Sebuah Tinjauan Administrasi", Pidato Pengukuhan Jabatan Guru Besar Dalam Ilmu Administrasi Pada Fakultas Ilmu Administrasi Universitas Brawijaya, Malang, 27 Mei 1995.

Manurung, Jonni J., Manurung, Adler H., Saragih, Ferdinand D 2005.Ekonometrika. Cetakan Pertama. Jakarta. Penerbit Elex Media Computindo.

Manurung, Jonni J., Manurung, Adler H.,2009. Ekonomi Keuangan dan Kebijakan Moneter.

Cetakan Pertama. Jakarta. Salemba Empat.

Nachrowi, DN dan Hardius Usman, 2006. Penggunaan Teknik Ekonometri, (Pendekatan Populer dan Praktis dilengkapi Teknik Analisis dan 
Pengolahan Data dengan Menggunakan paket Program SPSS), edisis revisi, Penerbit ; PT.Raja Grafindo Persada, Jakarta

Nanga, M. 2006. Dampak Transfer Fiskal Terhadap Kemiskinan di Indonesia. Disertasi Nopirin.2000. Ekonomi Moneter. Buku II. Edisi ke 1. Cetakan Kesepuluh. BPFE UGM.Yogyakarta.

Pohan, Aulia.2008. Potret Kebijakan Moneter Indonesia. Cetakan Pertama. Jakata. PT. Raja Grafindo.

Rahayu, S., Sondi, K., dan Adang, R. 2000. Analisa Pemerataan Pendapatan Usahaternak Sapi Perah Rakyat (Survey Pada Peternakan Sapi Perah Rakyat di KUD Mitra Yasa Kabupaten Tasikmalaya). Fakultas Peternakan, Universitas Padjadjaran. Sumedang.

Samuelson,Paul A. dan Willian D. Nordhaus (2004) Makro Ekonomi. Jakarta : Erlangga. Sunarwan Arif Wicaksana (2007) Analisis Kesenjangan Kemiskinan Antar Propinsi di Indonesia Periode Tahun 2000-2004. Universitas Islam Indonesia.

Todaro, Michael P. (2000). Economic Development. Seventh Edition. United Kingdom.Addison-Wesley.

Todaro, Michael P. (2000). Pembangunan Ekonomi Di Dunia Ketiga. Edisi Keempat. Jakarta : Erlangga.

Usman, Bonar M. Sinaga, dan Hermanto Siregar (2004) Determinan kemiskinan sebelum dan sesudah desentralisasi fiskal. Tesis. Tidak Dipublikasikan.

Wahyu A.P, Paidi H, 2007, Pedoman Praktis Penggunaan Eviews Dalam Ekonometrika, USU Press, Medan

World Bank Institute. 2002. Dasar-dasar Analisis Kemiskinan. Edisi Terjemahan. Badan. Hermanto Siregar (2008) Dampak Pertumbuhan Ekonomi Terhadap Penurunan Jumlah Penduduk Miskin. IPB \& Brighten Institute. 